\title{
IMAGINING AND IMAGING BORDERS: UNDERSTANDING BORDERLANDS FOR GLOBAL SUSTAINABILITY
}

\author{
Victor Konrad \\ Department of Geography and Environmental Studies, Carleton University, Ottawa, Canada - \\ Victor.Konrad@carleton.ca
}

KEY WORDS: Border, Boundary, Borderlands, Governance, Flows, Border Culture, Border History, Security, Sustainability

\begin{abstract}
:
Borders are increasingly complex human responses and social constructions in a world where globalizing forces confront basic human concerns for security and certainty. In an effort to provide a background to assess research directions for imaging borders, this paper explores what we know about borders, and what we do not know well about borders. Borders in globalization are the meeting points of globalizing forces of security, trade and migration flows with emerging technologies, self determination and regionalization around the world. We need to know more about how: self determination fuels secessions and new borders; borders result from complex rather than simple policy and governance issues; borders depend on the political clout of borderland communities; market and migration flows impact borders; and borders are always in motion. The paper shows how these organizing principles underlie the basic themes of border governance, flows, culture, history, security and sustainability. Finally, the paper offers two brief illustrations of border imaging to link this presentation to the following discussion of the workshop.
\end{abstract}

\section{INTRODUCTION}

Borders represent the edges of the reified imaginaries of polities and societies, their power and their territorial control. Borders are at once real and imagined. They divide and they are crossed. They are lines and transitions. Borders are limits and opportunities. Borders are binaries, and in the 21 st century, binaries are the quintessential act of bordering and of crossing borders. Borders, then, are increasingly complex human responses and social constructions in a world where the globalizing forces of instant communication, expedited travel and enhanced economic flows, confront the basic human concerns for security and certainty.

Imaging borders is framing what we see. The border is caught in time and space. It would be ideal if we could capture and integrate the cumulative images of the globe to interpret what borders and bordering are doing to the world. What is the effect of borders in globalization? How do borders re-arrange spatial effects? How can we record the images of border effects? Before we address these and other questions about imaging borders, it is instructive to understand how borders work. My goal is to provide a conceptual framework for border studies. My hope is that this framework may help you to develop the tools and approaches to image borders.

In this presentation, first I will explore what we know about borders, how they originated, and the approaches that scholars have employed traditionally to unravel what they mean. Then, I will focus on what we do not know well about borders, and the problems and challenges of understanding borders in globalization. Next, I offer some themes and organizing principles for studying borders in various geographical contexts. Finally, we will examine a few examples of where and how imaging borders may help us to understand boundaries and borderlands more effectively.

\section{WHAT WE KNOW ABOUT BORDERS}

Borders are certainly as old as cities with their walls, districts, enclaves and spatial distinctions, and borders may pre-date urban societies in many parts of the world. In southern Ontario,
Canada, where I come from, there has been a boundary of culture, language and life ways in place between Iroquoian and Algonkian indigenous peoples for thousands of years. Yet, archaeological evidence confirms that these peoples emerged from a common ancestry. How and why did the border between them emerge? We may never know how and why the Iroquoian-Algonkian border was constructed in pre-historic Ontario, but there is evidence and knowledge of how borders grew in importance in the post-classical world. What we do know is that by the 17 th century boundaries were being enshrined in law. The Treaty of Westphalia is commonly purported to be the first of a long line of international treaties that established the tenets of sovereignty and the control of violence and oppression, all within territorial limits.

In the 18th and 19th centuries, according to my colleague Emmanuel Brunet-Jailly (2010), borders entered a disciplinary era in which societies implemented power, and established a set of instruments and techniques to consolidate territory, particularly as imperial expansion rolled around the globe. Procedures were established to identify, formalize and finalize borders. Some borders were applied differentially based on the need for security and the development of technologies. Borders in this disciplinary era were essentially anti-nomadic devices of power and control.

Today, we are in an era of surveillance borders. Surveillance is everywhere, and certainly where goods and people cross territorial boundaries or embark on flights and trajectories across these boundaries. The body has become the password in a coded flow (Salter, 2010). The body allows access and status. Each individual person or good is the key to crossing the border. Over time, we have developed genealogical approaches to borders. We historicize borders and focus on how boundaries are sites of technological control of people and goods within territories (Walters, 2004). As Agnew (1994) has pointed out, we have been caught in the territorial trap of viewing the nation-state as synonymous with power and specific territory. Territorial limits, boundaries and borders have become synonymous. Yet, in our lifetimes, in the process of globalization, spaces of places have become spaces of flows that are always evolving (Agnew, 2009). Nevertheless, our 


\section{5 - 6 December 2013, Beijing, China}

disciplinary societies continue to enforce the boundary lines of territories which remain the containers of sovereignty. Within these containers, and to cross their boundaries, we need identity cards, passports and visas.

Border security vis a vis boundary security is more comprehensive because with air travel and more types of flows borders are everywhere (Salter, 2012). Border security has led to surveillance societies in which we enforce preclearance of goods and people. People are bordered in and bordered out with iris scans, finger prints and other emerging biometrics. Surveillance societies are developing differently around the globe. The European Union removes historical boundaries internally but generalizes border control across vast transboundary regions and a vast array of policies within the EU. The EU develops good neighbour policies at its periphery yet enforces the Shengen line with vigour, particularly in the face of unwanted refugee claimants. North America, now generalizes preclearance, but it is reducing internal borders more slowly if at all. Africa is still shoring up post-colonial borders although the separation of North and South Sudan may be an indication of a new order in the making. Here in the Sudan, and across the sub Sahara, the Islamic Front is actually the prevailing border and a mobile border. Asia conveys a complex of overlapping maritime boundaries, anchored in part by outlying islands, and evolving land borders with barriers, tension zones and flash points.

\section{WHAT WE DO NOT KNOW WELL ABOUT BORDERS}

Increasingly, we are becoming aware that people are the key to border crossing, but where is the lock? The challenge is that borders are vacillating, unpredictable, volatile, mobile, and arbitrary (Balibar, 2002). As Castells (2000) and others remind us, spaces of places have changed to spaces of flows, and, increasingly, these spaces of flows are wireless and virtual. Securing these flows is becoming ever more political and representational as we seek an accountability of space in a bordered yet unbounded world (Jones, 2012).

Borders in globalization are the meeting points of globalizing forces of security, trade and migration flows with emerging technologies, self determination and regionalization around the world. Key discussions in the literature are organized around six major organizing principles (Brunet-Jailly, 2005, Foucher, 2007, Konrad and Nicol, 2008).

The first is that self-determination fuels secessions and new borders following an order established by the Treaty of Westphalia (1648) and reified for the modern world in the Treaty of Paris (1919) (Macmillan, 2003). These treaties enshrined sovereignty - the exclusive right of the exercise of legitimate violence within the limits of territory. Self determination and sovereignty have become global organizing principles, and since the creation of the United Nations in 1945, the signatory states have expanded from 51 to almost 200 . Moreover, since the 1990s, negotiations related to boundary delimitations have expanded prodigiously (Foucher, 2004). Since 1991, about 26,000 kilometres of new political boundaries have been added to the world map (Foucher, 2007). The fences, barriers and walls now evident, if placed end to end, would extend for 29,000 kilometers (Rosiere and Jones, 2012, Vallet, 2012). Our understanding of why this is happening remains rudimentary.

Borders result from complex rather than simple policy and governance issues. Yet, during the early $20^{\text {th }}$ century, scholars sought simple explanations for the purpose and nature of boundaries. They were viewed as places where humans could not settle (marchlands), buffer zones of mediation, military regions for combat rehearsals, zones of economic equilibrium and spaces to ease tensions (Minghi, 1963). Today, borders are understood as institutional constructs (Newman and Paasi, 1998) arising from international agreements among consenting states. But they are also concretized policies, means for enforcing lines of demarcation, with border gates, patrols, and technologies (Salter, 2010, 2012). This multiplicity of specific functions has recently been conceptualized by scholars as "policy networks and multilevel governance" in the bordering process (Marks and Hooghe, 2001, Brunet-Jailly, 2004). Specifically, borders are understood to be "complex, intermeshed networks of government agencies with policies and functions that interact to delineate sovereign spaces, and coproduce border security" (Brunet-Jailly, 2007). Since the events of 9/11, most national governments have re-invested heavily in border security, particularly in North America and Europe. The assumption is that technological modernization enhances control over border porosity. Although the fall of the Berlin Wall was emblematic of the disintegration of state sovereignty, the obsolescence of the nation state, the emergence of new transnational and supra-national groupings, and a new era without borders and limits, the post-9/11 era has seen the rise of border walls, symbols of seemingly unfinished separation. Building walls unilaterally freezes a boundary line, and it is a process that is no longer bilateral or multilateral. In the $21^{\text {st }}$ century, borders are moving from being zones of contact and influence (Soutou, 2009) to barricades around peoples as states retreat into the security of world-wide neo-feudal reflexes (Vittori, 2007), in spite of an emerging more globalized world with less economic and communication constraints.

Borders depend on the culture of local borderland communities. The border studies literature suggests that culture can either emphasize the territorial division of language, ethnicity, socieconomic status, and place of belonging, or it can bridge a shared international boundary. Case studies of borderland communities spanning international boundaries suggest that nations (not nation-states) remain an important phenomenon. In Asia, Europe and North America, these nations challenge basic assumptions of primacy-of-state ideology and domination. Stateless nations are bounded by culture (Keating, 2001) and so may challenge the mere institutional functions of borders (Paasi and Newman, 1998). Scholars have identified the crucial role of borderland communities as organized polities inside the larger institutional architecture of belonging, underlining the importance of local culture. Indeed, although international borders divide stateless nations, borderland communities may remain unified by culture (ethnicity, language and/or religion) or local political institutions (Konrad and Nicol, 2011). Their capacity for local political organization and activism influences the very nature and functioning of the boundary. Indeed, there is a wealth of scholarly explanations of how non-central-state actors, pluri-national communities, and stateless nations perforate or undermine the integrity of state borders. Essentially, the unifying, symbolic, dividing and exclusionary role of borders, as a founding principle of a sovereign state, is currently under pressure.

Borders depend on the political clout of borderland communities. Cross-border communities either work (cooperate and link) or they do not work (tension, inequalities). Few borderland communities have institutions that span an international border but there are many instances of established linkages and many examples of local cross-border tensions (Clarkes, 2000). Bi-national cities could represent either tensions or linkages or both. The literature documents local tensions with the central state; local divergence of views across 


\section{5 - 6 December 2013, Beijing, China}

the border; local multi-cultural tensions and wide bi-national differences despite shared infrastructures; and local tensions despite strong economic linkages. The multiple policy activities of governments, the local culture and political clout of borderland communities, may all be fundamental elements of border security policy. There is a critical value in local political activism and culture for understanding borders.

In a globalizing world, however, we need also to contemplate beyond community and locale to situate borders. Market and migration flows have significant implications for borders. The specific exigencies of flows of people, goods, information and currencies at borders and in borderlands have yet to be understood fully. In the Economics of Location Loesch (1954) reasoned that borders are costly because they are barriers to trade, and particularly the free flow of goods, labor and skills. Helliwell (2002) has argued that borders continue to matter despite some economic integration because they delineate the boundaries of governments. Hale and Gattinger (2010) add that borders circumscribe social networks and human interactions. Ohmae (1996) shows how trans-border economic regions emerge out of culturally homogeneous borderland regions. In arguing that spaces of places are replaced by spaces of flows, Castells (1997) suggests that "the modern nation state has lost much of its sovereignty". Combined, these arguments show that flows of goods, capital and migrants not only limit the influence of central governments but also modify local cultures and political identities, and acknowledge the influence of market forces on borders.

Finally, borders are always in motion. Part of this notion is historical. It is explained in the fact that communities, nations, states and empires, and the borders between them, are constantly in the making and un-making (Davis, 2011). Borders are also malleable and adaptable to this nation-state construction and re-construction (O'Dowd, 2010). It is the variability of linkages between economic, politico-juridicial, ideological-cultural, and military/policing dimensions of infrastructural power, argues O'Dowd (2010:1035), that "shapes the nature and significance of state borders [and] makes historical analysis imperative as a means of understanding changing state borders." Acceptance of the historical variability of borders, combined with their malleability, and the sense that borders are constantly imagined, contested and reconstructed through time, helps us to begin to comprehend and express border mutability in time and space. Yet, theorizing about borders in motion is just beginning at all geographical and temporal scales.

\section{HOW WE MAY APPROACH THE STUDY OF BORDERS IN GLOBALIZATION}

The six organizing principles have emerged worldwide through the work of individual scholars, but, moreover, through the interaction and cross-disciplinary cooperation promoted largely during the last two decades in several border studies networks (Border Regions in Transition, East Border Net, Asian Borderlands Research Network, African Borderlands Research Network, The Association for Borderlands Studies). Most of these networks have developed major, collaborative research projects centered in the European Union, Japan, the United States and now Canada. The Borders in Globalization (BIG) project is an innovative, integrative and sustainable partnership among already productive networks of academics in Canada, the U.S., Europe, Asia and the Middle East who are engaging with non-academic organizations involved in managing borders and borderlands in Canada and worldwide. The goal of this Canada-led initiative is to promote further excellence in border studies, create new policy and foster knowledge transfer in order to address globalizing forces of security, trade and migration flows, and to understand the challenges of emerging technologies, self-determination and regionalization, around the world, affecting borders and borderlands. In order to achieve this goal, BIG is fostering integrated comparative and international practice and analysis, which will in turn also inform professional and academic training. A central tool is the roundtable discussion among policy-makers and academics where research questions related to organizing themes are developed and discussed. The themes and sub themes currently being discussed in the roundtables are:

1) Changes in the governance of borders in globalization: The significant changes from state control to greater supra-national and sub-national, and public and private (non-state actors) engagement, has made governance of borders layered and complex. Emerging governance issues are a) regional security governance, b) multi-level border governance, c) regional and local governance and policy networks, d) governance of security, e) governance of sustainability, g) governance of migrations.

2) Market and migration flows: International trade expansion and just-in-time requirements in global production areas, and migration and market flows, have resulted in corridor development, hierarchies of crossings, pre-clearance procedures, countries of origin issues, border infrastructure expansion and unprecedented change in the nature and operations of business across borders. Global migrations and diaspora are often but not always related to market flows due the variation of skilled and unskilled migrants. Emerging flows components are: a) regional integration across borders, b) supply chains, c) transportation corridors, d) agricultural trade and safety, e) regional trade politics, f) labor and immigration flows, g) unskilled labor, h) illegal and shadow work, sex work. 3) Changes in border culture and historical perceptions: Cultures are changing with the advent of globalization, yet culture remains the anchor of cross-border relationships, practices and other forms of continuity. Culture at borders is increasingly scaled and differentiated, re-constructed, enacted and otherwise expressed to link and validate land and life in the borderlands. Border culture has many facets but these may be approached under the following subthemes: a) indigenous cultures/self determination, b) circumpolar culture, c) border culture and globalization, d) culture and continuity across borders, e) border communities and cultural linkage, f) borderlands cultural/spatial constructs, g) cultural integration/ disintegration dynamics.

4) Directions in the study of border history: Understanding borders in globalization requires understanding the emergence and evolution of boundaries between states and cultures, and how societies have constructed borders. Subthemes are: a) migration and borderlands, b) borderlands trade history, c) cross-border investment over time, d) evolution of borderland regions, e) emergence of borderland cultures and identities, d) immigration history.

5) Sustainability issues: Whereas continental environmental stewardship efforts have seen limited success with the advent of globalization, local and sub-national cooperation to sustain and protect the environment has exhibited accomplishment and success, particularly between the U.S and Canada. Questions of scale, agency, institution, and governance are leading concerns in addressing environmental stewardship in the borderlands. Immediate concerns are: a) security enhancement and environmental concerns, b) environmental crisis and cooperation, c) fences, barriers and environmental sustainability, d) sustainability and immigration, e) shared 
waterway management, f) changing arctic ecology, g) cooperative trans-border arctic resource management, $h$ ) food security within and across borders

6) The enhancement of security: Security at borders has coincided with the increased global movement of goods and migration of peoples. Diaspora and increased global travel are impacted in various ways as states fortify borders and differentiate human movement across them. Meanwhile, goods are increasingly channeled in regulated flows and expedited with substantial investments in technology. The borderlands are increasingly contested places and conflict zones as the perception of them as spaces of difference in globalization emerges. Subthemes are: a) risk management and public communication of risk, b) bilateral and asymmetric relationships (Canada, U.S., EU), c) security perimeter, d) biometric and document security, e) aviation security, f) terrorism and borders, g) cross-border terrorist and criminal networks.

\section{IMAGING BORDERS AND BORDERLANDS WITHIN THE MATRIX OF BORDERS IN GLOBALIZATION}

Clearly, within this emerging list of themes and subthemes, there are numerous topics for research that would gain from scientific imaging of the borders and borderlands. If we examine the context of Canada alone, a matrix of themes and regions emerges, and one may envision examining any one of the topics above within the Arctic region for example, or in any of the Canadian regions stretching across the continent. I will limit my discussion of potential border imaging projects to two examples.

The first illustration is from the Arctic region where the boundary between the United States and Canada divides the range of the Porcupine caribou herd (figure 1). The animals characteristically roam over a territory that extends from just west of the Mackenzie River to the North Slope of Alaska. The herd has diminished over the last three decades due to increased hunting pressure, but more decidedly because of oil exploration and drilling either close to or inside the caribou range, and specifically the calving grounds on the Alaska North Slope. Efforts to extend oil drilling into the 1002 Area a decade ago have been thwarted by conservationist pressure, but the herd remains under pressure and now appears threatened by changing climatic patterns in the region that have increased predation by other animals as well as insect pests. Partial protection is afforded by the Arctic National Wildlife Refuge and the Venetie Indian Reserve in Alaska, and Ivvavik Natioal Park, Vuntut National Park, and the Old Crow Flats Special Management Area in the Yukon Territory.

The problem for wildlife managers is to integrate different research and management procedures, protocols and priorities across the border to meet the regulations and expectations of Inuit and Indian stakeholders, government stewardship agencies, resource extraction companies, and conservation groups on both sides of the border. Cross-border imaging that is consistent and integrative is required to establish herd migration movements, numbers of caribou, changes in forage potential, predation impacts and other variables in order to assess management practices and determine the future of the herd.

Similar cross-border integrated imaging is required to assess wildlife, forests and other resources in the Arctic as well as the other cross-border regions along Canada's southern boundary. It is simple to extrapolate similar situations elsewhere including along the Chinese border with Russia.

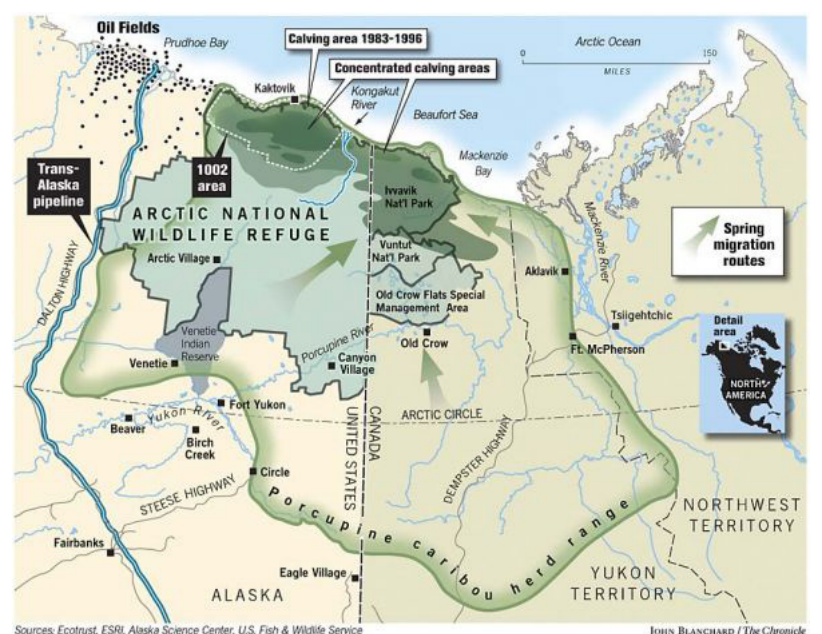

Figure 1 The Porcupine Caribou Herd and the Border between Alaska and the Yukon Territory

It is evident that the Canada-U.S border crosses many ecosystems. Indeed, this fact has been recognized for well over a century and agencies like the International Joint Commission have been established specifically to mediate water and air quality concerns originating in the borderlands. Also, it is apparent that these ecosystems are dynamic and that, increasingly, they are impacted by large scale as well as local climate change. The Lake Champlain Basin is nestled between the Adirondack Mountains of New York and the Green Mountains of Vermont, and it extends north into Quebec to the St. Lawrence River. The Basin crosses state and international boundaries. The prospect of deteriorating water quality under climate change scenarios will impact indigenous Abenaki people (water and food), recreational communities (boating and fishing), urban communities (potable water) and farming communities (revenues from tourism and food) in and near the Basin. Moreover, it will complicate even further the already difficult meshing of water quality regulation and conservation across state and international boundaries.

To monitor the changes in water quality a combination of approaches has been advocated by Brown and Zia (2013) in their proposal to the North American Commission for Environmental Cooperation. The program includes remote sensing of

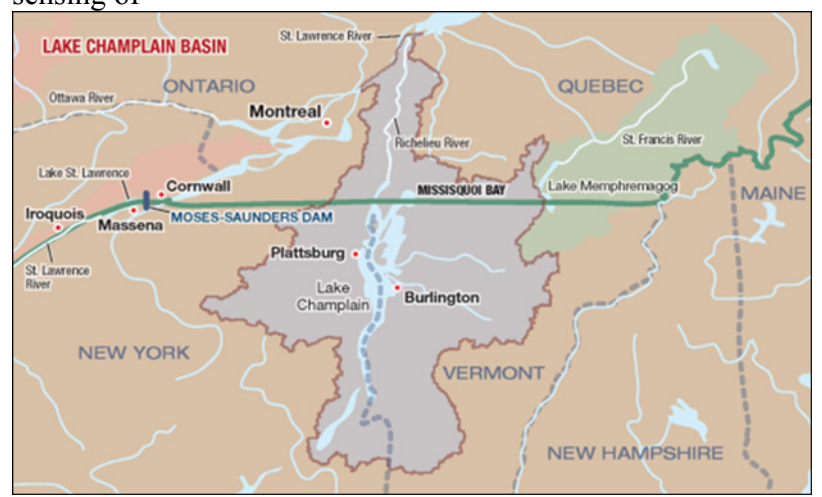

Figure 2. Lake Champlain Basin

Basin water level and quality characteristics combined with participatory GIS (PGIS) to increase resiliency of the linked socio-cultural and physical resource systems. Sequenced mapping of physical and human resource variables involved in nutrient loading will deploy remote sensing and other traditional GIS tools. Then, PGIS, a practice in which local communities share knowledge and opinions, and relevant geospatial data, is used to generate maps and other spatial 


\section{5 - 6 December 2013, Beijing, China}

information products to inform decision-making. The overall effect is a more robust research approach which improves the capacity for adaptive resource management as well as the engagement of communities found on different sides of the borders as well as those like the Abenaki and recreation communities which extend across the border.

\section{CONCLUSIONS}

Although I have provided a few very preliminary and general examples of how imaging borders and borderlands may offer more effective lenses with which to view the rapidly changing environments across boundaries, there are many other border issues that may be understood more effectively through the application of remote sensing. Among these are applications to address issues of security, governance, trade and migration flows, as well as the more subtle yet significant border effects of history and culture.

This paper, however, is not a template for how to accomplish the imaging of borders and borderlands. That is your expertise. My goal has been to present an overview of what border studies specialists know about the state of borders and borderlands, and an assessment of where border studies is headed. one point is very clear to the scholarly community in border studies, and that is that we must work with the policy community of border stakeholders to identify research directions. Another point is just as important: the development and accomplishment of effective research strategies depends on collaborative research with colleagues in cognate fields like remote sensing to sharpen the resolution and the vision of border studies. Thank you for the opportunity to share with you in this timely and important work.

\section{References}

Agnew, J. 1994. The Territorial Trap: The Geographical Assumptions of International Relations Theory, Review of International Political Economy 1, 1: 53-80.

Agnew, J. 2009. Globalization and Sovereignty. Rowman and Littlefield.

Balibar, E. 2002. Politics of the other scene. Verso.

Brown, C. and A. Zia. 2013 Environmental diplomacy and community-based efforts to enhance resilience of the Lake Champlain Basin Ecosystem. Proposal to CEC, Montreal.

Brunet-Jailly, E. 2004. NAFTA, economic integration and the Canadian-American security regime in the post-September 11, 2001, era: Multi-level governance and transparent border? Journal of Borderlands Studies 21, 1.

Brunet-Jailly, E. 2005. Understanding Borders: A Model of Border Studies Geopolitics 10, 4: 633-649.

Brunet-Jailly, E. 2007. Borderlands: Border Security in Europe and North America in Comparative Perspective. University of Ottawa Press.

Castells, M. 2000. The Rise of the Network Society. Blackwell.
Clarkes, S. 2000. Regional and transnational discourse: The politics of ideas and economic development in Cascadia International Journal of Economic Development 2, 3: 360-378.

Davis, N. 2011. Vanished Kingdoms: The History of HalfForgotten Europe. Allen-Lane.

Foucher, M. 2004. Fronts et Frontieres. Fayard.

Foucher, 2007. L'obsession des Fontieres. Librairie Academique Perrin.

Hale, G. and M. Gattinger. 2010. Borders and Bridges: Canada's Policy Relations in North America. Oxford.

Helliwell, J. 2002. Globalization and Well Being. University of British Columbia Press.

Jones, R. 2012. Spaces of refusal: Rethinking sovereign power and resistance at the border Annals, AAG 102, 3: 685-699.

Keating, M. 2001. Plurinational Democracy: Stateless Nations in a Post-Sovereignty Era. Oxford.

Konrad, V. and H. N. Nicol. 2008. Beyond Walls: RE-Inventing the Canada-United States Borderlands. Ashgate.

Konrad, V. and H. N. Nicol. 2011. Border Culture, the Boundary Between Canada and the United States of America, and the Advancement of Borderlands Theory Geopolitics 16: 70-90.

Loesch, A. 1954. The Economics of Location. Yale. Macmillan, M. 2003. Paris, 1919. Random House.

Marks, G. and L. Hooghe. 2001. Multi-Level Governance and European Integration. Roman and Littlefield.

Minghi, J. 1963. Review article: Boundary studies in political geography Annals, AAG 53, 3: 407-428.

Newman, D. and A. Paasi. 1998. Fences and neighbors in the post-modern world: Boundary narratives in political geography Progress in Human Geography 22, 2: 186-207.

Ohmae, K. 1996. The End of the Nation State. Free Press.

O' Dowd, L. 2010. From a 'border-less world' to a 'world of borders': bringin g history back in Environment and Planning D. Society and Space 28, 3: 1031-1050.

Paasi, A. 1998. Boundaries as social processes: Territoriality in the world of flows Geopolitics 3, 1: 69-88.

Rosiere, S. and R. Jones. 2012. Teichopolitics: Re-considering globalization through the role of walls and fences Geopolitics 17, 1: 217-234.

Salter, M. 2010. Mapping Transatlantic Security Relations: The EU, Canada, and the War on Terror. Routledge.

Salter, M. 2012. Citizenship, borders and mobility: Managing Canada's population, in C.T. Sjolander and H. Smith, eds, Canada in the World, Perspectives on Canadian Foreign Policy. Oxford.

Soutou, G-H. 2009. L'Europe de 1815 a nos jours.PUF.

Vallet, E. and C. David. 2012. Un Mur pour Frontiere. Presses de l' Universite du Quebec.

Vittori, J-P. 2007. Eux, les S.T.O. Ramsay.

Walters, W. 2004. The frontiers of the European Union: A geostrategic perspective Geopolitics 9, 3: 674-698. 